\title{
FGFRL1 wt Allele
}

National Cancer Institute

\section{Source}

National Cancer Institute. FGFRL1 wt Allele. NCI Thesaurus. Code C51545.

Human FGFRL1 wild-type allele is located within 4p16 and is approximately $16 \mathrm{~kb}$ in length.

This allele, which encodes fibroblast growth factor receptor-like 1 protein, plays a role in mitogenesis and differentiation. 